\title{
Biological treatment of petroleum contaminated soils by soil slurry-sequencing batch reactors (SS-SBRs)
}

\author{
B. Torabifar ${ }^{1}$, A. $\operatorname{Torabian}^{1}$, A. A. Azimi ${ }^{1} \&$ M. Vossoughi ${ }^{2}$ \\ ${ }^{1}$ Faculty of Environment, University of Tehran, Tehran, Iran \\ ${ }^{2}$ Department of Chemical and Petroleum Engineering, \\ Sharif University of Technology, Tehran, Iran
}

\begin{abstract}
The soil slurry-sequencing bath reactor (SS-SBR) was studied to treat poorly graded sand with clay (SP-SC) contaminated by aged petroleum hydrocarbons and polycyclic aromatic hydrocarbons (PAHs) with concentrations of 23000 $\mathrm{mg} / \mathrm{kg}$ and $750 \mathrm{mg} / \mathrm{kg}$ respectively. An $8 \mathrm{~L}$ bioreactor was operated with a $10 \%$ solid concentration $(0.1 \mathrm{~kg}$ dry soil/L slurry). The fill period was relatively instantaneous, and the draw period lasted approximately 1 minute so the react period comprised essentially the entire cycle time. In the draw period a fraction of slurry $(10 \%)$ was removed from the SS-SBR weekly and it was replaced with untreated slurry. This volumetric replacement strategy provided 70 days hydraulic retention time (HRT). The process performance was assessed by monitoring total petroleum hydrocarbons (TPH) and $\mathrm{PAH}$ concentrations, $\mathrm{pH}$, dissolved oxygen (DO), oxygen uptake rate (OUR) and colony forming units (CFU). Due to a high concentration of TPH, silica gel clean up was performed to specify PAH degradation. The results have shown high overall removal efficiency for TPH close to $97 \%$ whereas biodegradation of PAHs has been performed with a removal efficiency of $90 \%$.
\end{abstract}

Keywords: petroleum contaminated soils, bioslurry, SS-SBR, TPH, PAH.

\section{Introduction}

For many years the soils of Azimabad, in the vicinity of the Tehran refinery plant, have been contaminated with petroleum hydrocarbons through spills, leakage of oil reservoirs, decay pipelines and refinery wastes. The intensity of 
pollution has affected even groundwater quality. In addition PAHs compounds, which are classified as environmental priority pollutants, are found in this area with high concentrations.

Bioslurry treatment, which is a relatively new application to contaminated sediments, soils and sludges clean up [1], is a biological ex situ technology, offering optimal process control and high biodegradation rate $[1,2]$ and could be operated in different modes such as batch systems tested $[3,4]$, tanks-in-series [5], soil slurry-sequencing batch reactor (SS-SBR) [6], continuous-flow reactor (CSTR) [7]. Among the above mentioned bioreactor types, SS-SBR and CSTR are the most common in field systems. At least for soil contaminated by hydrocarbons, SS-SBRs are able to reach higher efficiencies than CSTR [8]. On the other hand SS-SBR has shown a good performance in treating PAH contaminated soils and sediments $[9,10]$, which are relatively persistent due to their hydrophobicity and stability [11].

\section{Materials and methods}

\subsection{The feed slurry}

Soil samples used in experimental studies were collected from a region in the vicinity of Tehran refinery plant in accordance with sampling procedure, described in chapter four of Test Methods for Evaluating Solis Waste, Physical/Chemical Methods (EPA, SW-846) [12]. The soil organic matter was determined by the Walkley-Black Method [13]. The soil was poorly graded sand with clay (SP-SC) according to Unified Soil Classification System (USCS) ASTM D 2487-93 [14]. Before using, the soil was passed through a $0.5 \mathrm{~mm}$ sieve. The sieved fraction was partially air-dried and was stored at $4^{\circ} \mathrm{C}$ to maintain biological activity. Prior to using in bioslurry experiments, the samples were spiked with a known concentration of PAHs including Naphthalene, Phenanthrene and Pyrene $(750 \mathrm{mg} / \mathrm{kg})$ dissolved in dichloromethane. Tap water

Table 1: $\quad$ Characteristics of the soil.

\begin{tabular}{ll}
\hline Soil Classification (USCS) & SP-SC \\
Composition of soil & \\
Sand (\%) & 90 \\
Silt (\%) & 3 \\
Clay $(\%)$ & 7 \\
Bulk density $\left(\mathrm{g} / \mathrm{cm}^{3}\right)$ & 1.7 \\
Soil $\mathrm{pH}(1: 2 \mathrm{w} / \mathrm{v})$ & 7.5 \\
Organic matter (\%) & 11 \\
Organic carbon & 6.4 \\
Soil moisture & 20.1 \\
$\quad$ Field (\%) & 12.3 \\
$\quad$ Air dried (\%) & $9 \times 10^{4}$ \\
CFU/g dry soil &
\end{tabular}


was added to produce a solids concentration of $10 \%(0.1 \mathrm{~kg}$ dry soil $/ \mathrm{L}$ slurry $)$. The Mineral Salt Medium (MSM) provides a $\mathrm{C}: \mathrm{N}: \mathrm{P}$ ratio of approximately 60:2:1 by adding ammonia, nitrate and phosphate as $\mathrm{NH}_{4} \mathrm{Cl}, \mathrm{KNO}_{3}, \mathrm{~K}_{2} \mathrm{HPO}_{4}$. Sodium sulphate $\left(\mathrm{Na}_{2} \mathrm{SO}_{4}\right)$ and Magnesium sulphate heptahydrate $\left(\mathrm{MgSO}_{4} \cdot 7 \mathrm{H}_{2} \mathrm{O}\right)$ were added with $2000 \mathrm{mg} / \mathrm{L}$ and $200 \mathrm{mg} / \mathrm{L}$ concentrations respectively. Since the samples were collected from an aged contaminated site, the endogenous microorganisms were supposed to degrade contaminants and therefore no adapted microorganism addition (bioaugmentation) was performed. The characterization of examined soil is indicated in Table 1.

\subsection{Bioreactor configuration}

The soil slurry-sequencing batch reactor (SS-SBR) consisted of sealed $8 \mathrm{~L}$ rounded bottom Plexiglas vessel with a working volume of $6 \mathrm{~L}(7 \mathrm{~cm}$ free board). The reactor was equipped with a $400 \mathrm{rpm}$ speed mixer. Oxygen was supplied through a fine-bubble diffuser at the bottom. Two ports were provided in the lid for housing dissolved oxygen (DO) and $\mathrm{pH}$ probes. A granular activated carbon (GAC) trap was used to collect volatile organics in effluent air. Since foaming is a common problem in bioslurry treatment, which is attributed to biosurfactant production $[15,16]$ and considering that foam production was reported in previous bioslurry SBR investigations [8], a siphon was provided in reactor to discharge probable foams. The reactor used for the experiments is shown schematically in Fig. 1. During studies, the reactor was maintained at relatively constant temperature $\left(23-25^{\circ} \mathrm{C}\right)$.

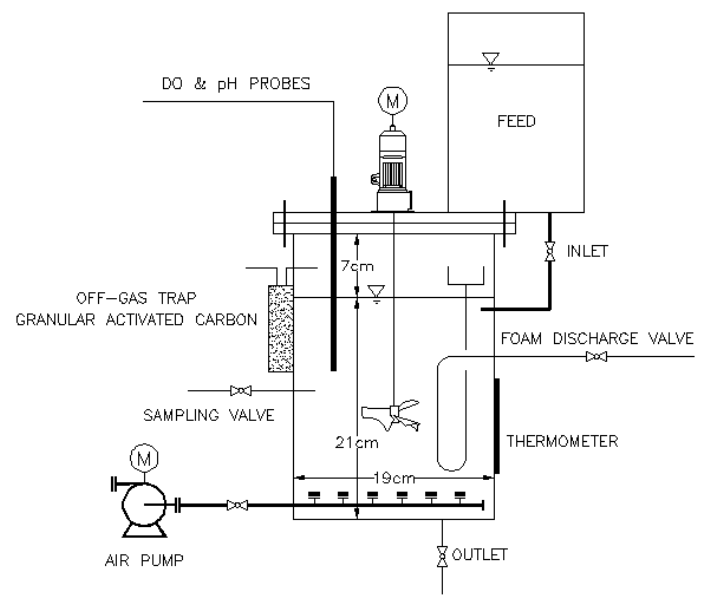

Figure 1: Reactor configuration.

\subsection{Bioreactor operation}

$6 \mathrm{~L}$ of prepared slurry was fed to reactor through the feed reservoir by gravity. The reactor was operated in sequencing batch mode. Fill period was relatively instantaneous, and draw period lasted approximately 1 minute so the react period 
comprised essentially the entire cycle time. In draw period a fraction of slurry $(10 \%)$ was removed from the SS-SBR weekly and it replaced with untreated slurry. This volumetric replacement strategy provided a 7 days solid retention time (SRT) and 70 days hydraulic retention time (HRT). A certain volume of slurry (the recycle fraction) remained in the reactor to provide acclimated microorganism for the next batch of untreated slurry.

\subsection{Analytical methods}

Fed and treated slurry were sampled during each treatment cycle for biological and physicochemical properties measurement.

\subsubsection{Physicochemical analysis}

The bioreactor was monitored regularly for slurry phase $\mathrm{pH}$, using $\mathrm{pH}$ meter (model 51935, HACH, USA) and dissolved oxygen (DO) using DO probe (model 51970, sensION6, HACH, USA). The Oxygen uptake rate (OUR) was evaluated for slurry samples decanted from bioreactor in duplicate according to Standard Methods (SM 2710 B) [17].

\subsubsection{Microorganism quantification}

After extraction of microorganisms from soil [18], pour plate method described in Standard Methods (SM 9215B) [17] was used to enumerate heterotrophic bacteria in quadruplicate. Dilutions were plated on plate count agar (Merck) and incubated for 48 hours at $37^{\circ} \mathrm{C}$. Colony forming units (CFU) were counted and reported as $\mathrm{CFU} \mathrm{g} \mathrm{g}^{-1}$ dry soil.

\subsubsection{Quantification of TPH and PAH}

Total petroleum hydrocarbons (TPH) and polycyclic aromatic hydrocarbons (PAH) concentrations were determined in the whole slurry and filtered slurry. Briefly, ultrasonic extraction was carried out on 2-5 g soil samples and $10 \mathrm{~mL}$ slurry filtered samples passed through the $0.45 \mu \mathrm{m}$ filter according to EPA $3550 \mathrm{~B}$ method [17]. $1 \mu \mathrm{L}$ of concentrated samples by Kuderna-Danish (K-D) concentrator was injected to GC (ATI, UNICAM, 610 series) equipped with FID detector for TPH quantification. Injection block and detector cell temperatures were $340^{\circ} \mathrm{C}$ and $280^{\circ} \mathrm{C}$ respectively. Concentration of PAH was supposed to be estimated by high performance liquid chromatography (HPLC) (Agilent, 1100 series) according to method described in EPA 8310 [17]. But due to high concentration of TPH, aspired separation of the aromatic and aliphatic could not completely be achieved. Hence silica gel clean up was performed based on method described in EPA 3630C [17] prior to injection.

\section{Results and discussion}

The SS-SBR was operated with a 7 day cycle. Hydraulic retention time of 70 days was achieved by replacing $600 \mathrm{~mL}$ of the slurry volume weekly. TPH concentration at the end of each cycle is shown in Figure 2. TPH concentrations were reduced from $23.0 \mathrm{~g} / \mathrm{kg}$ in the feed slurry to $0.75 \mathrm{~g} / \mathrm{kg}$ after treatment in the 
SS-SBR. This represents a removal efficiency of 97\% (Fig. 3). Rates of TPH removal in SS-SBR showed a considerable decrease at first two weeks of operation.

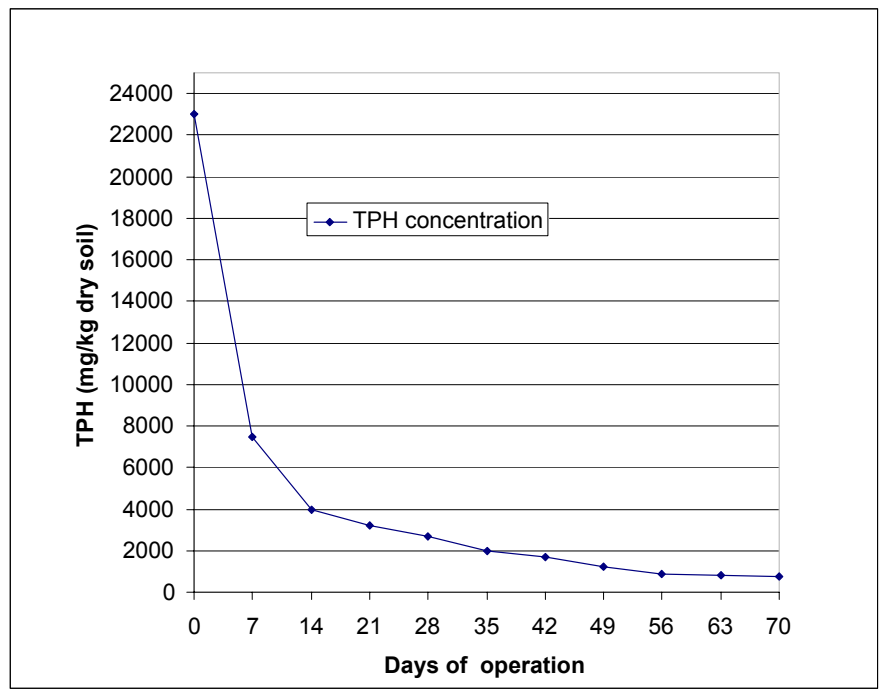

Figure 2: $\quad$ TPH concentration during 70 day HRT.

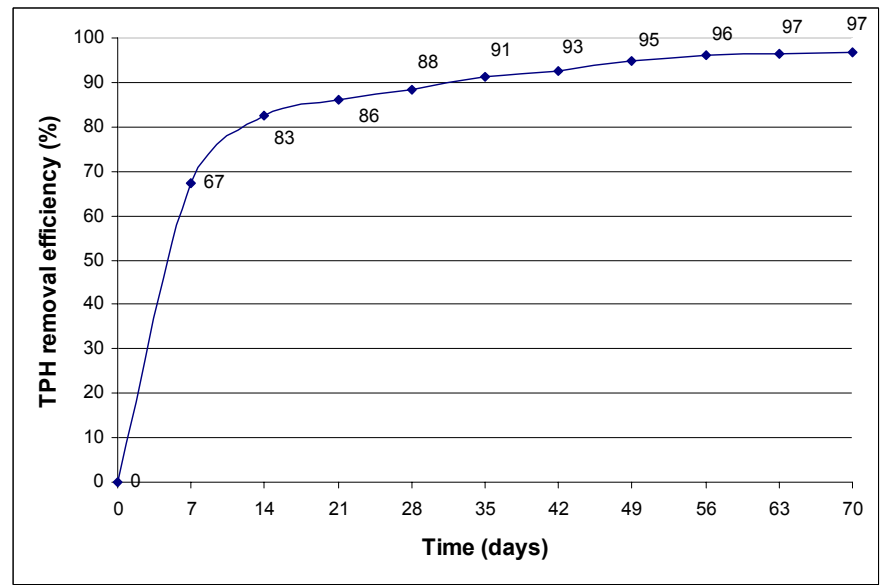

Figure 3: $\quad$ TPH removal during 70 day HRT.

PAHs biodegradation was investigated in the SS-SBR simultaneously. The results are shown in Figure 4.

Time profile of oxygen uptake rate (OUR), used as a surrogate measure of biological activity in bioreactor is shown in Figure 5 during operation period. OUR increased in the SS-SBR from approximately $1.78 \mathrm{mg} / \mathrm{L} / \mathrm{hr}$ to $8.3 \mathrm{mg} / \mathrm{L} / \mathrm{hr}$. 
756 Waste Management and the Environment IV

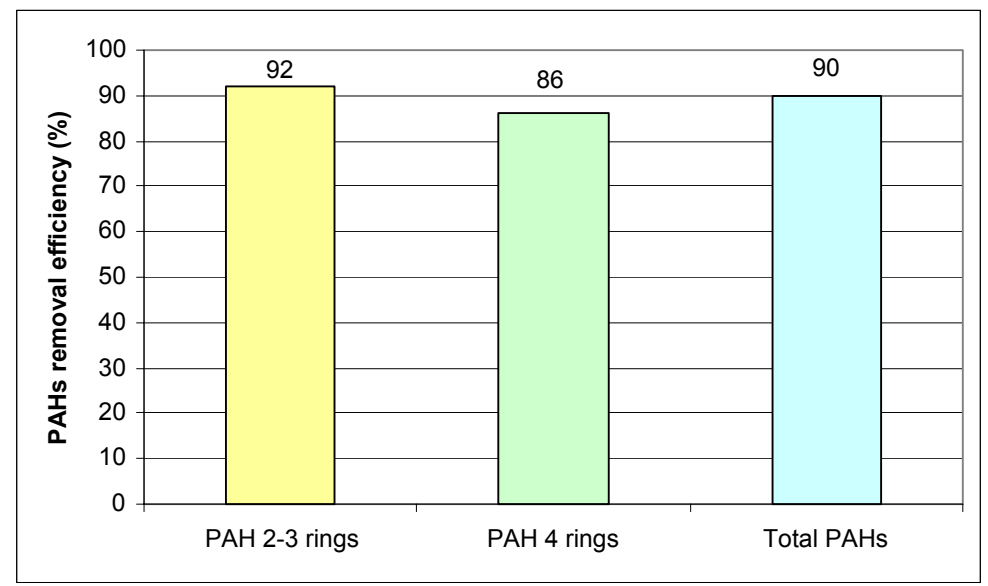

Figure 4: $\quad$ PAHs removal efficiency during bioreactor operation.

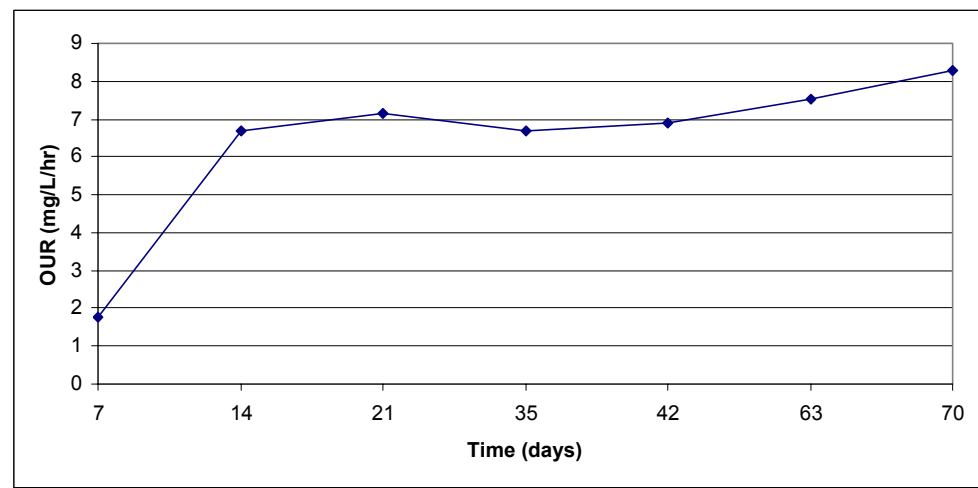

Figure 5: $\quad$ OURs for the SS-SBR during 70 day HRT.

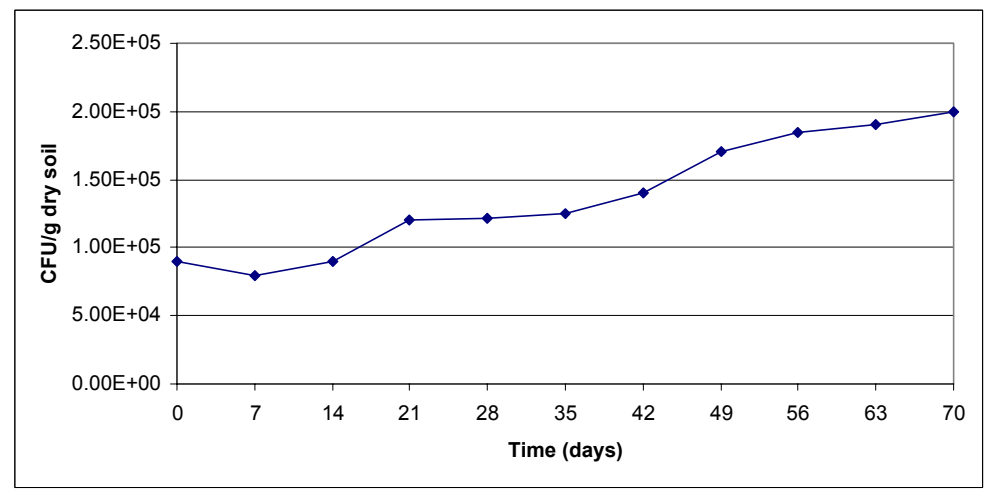

Figure 6: $\quad$ CFU versus time during bioreactor operation. 
Results from microorganisms are shown in Figure 6. During the first week after fill, CFU did not increase. While after one week, bacterial counts began to grow up.

Table 2 lists the results of measurements made in the feed and effluent from the SS-SBR at the end of operation.

Table 2: $\quad$ Results of measurements from the feed slurry and the SS-SBR effluent.

\begin{tabular}{|c|c|c|}
\hline Parameter & Feed & Effluent \\
\hline TPH $(\mathrm{mg} / \mathrm{kg}$ soil $)$ & 23000 & 750 \\
PAHs $(\mathrm{mg} / \mathrm{kg}$ soil $)$ & 750 & 75 \\
OM $(\%)$ & 11.0 & 3.9 \\
OC $(\%)$ & 6.4 & 2.3 \\
$\mathrm{pH}$ & 7.6 & 7.3 \\
CFU $\times 10^{4} / \mathrm{g}$ dry soil & 9 & 20 \\
\hline
\end{tabular}

\section{Conclusions}

The experiments demonstrated that TPH was reduced in the SS-SBR from a concentration of $23 \mathrm{~g} / \mathrm{kg}$ in the feed slurry to $0.75 \mathrm{~g} / \mathrm{kg}$ in the reactor effluent at the last cycle of operation. Successful degradation of stable and hydrophobic compounds such as PAHs were also accomplished. Indeed an overall removal efficiency of $90 \%$ was achieved in 70 days HRT. However the removal efficiency was higher for 2-3 rings PAH (removal efficiency of 92\%) rather than 4 rings $\mathrm{PAH}$ (removal efficiency of $86 \%$ ).

\section{References}

[1] U.S. EPA, Engineering Bulletin: Slurry Biodegradation, Center for Environmental Research, EPA/540/290/016, OH, 1990.

[2] Riser-Roberts, Eve. (1998). Remediation of petroleum contaminated soils: Biological, Physical, and Chemical processes. Boca Raton, Lewis Publishers.

[3] Jerger, D.E., Cady D. J., Exner, J.H. (1994). Full-scale slurry-phase biological treatment of wood preserving wastes. In Bioremediation of Chlorinated and Polycyclic Aromatic Hydrocarbons (edited by Hinchee, R. E., Leeson, A. Semprini, L., Ong, S. K.), pp. 480-483, Lewis Publishers, Boca Raton.

[4] J.A. Glaser, J.W. JimTzeng, P.T. Mac Cauly, Slurry biotreatment of contaminated soils, in: R.E. Hinchee, G.D. Sayles, R.S. Skeen (Eds.), Biological Unit Processes for Hazardous Waste Treatment, Battle Press, Columbus, OH, 1995, pp. 145-152.

[5] Kleijntjens, R. (1991). Biotechnological Slurry Process for Decontamination of Excavated Polluted Soils. Doctoral Dissertation, Technical University of the Delft, The Netherlands 
[6] R.L. Irvine, P.S. Yocum, J.P. Earley, R. Chozick, Water Sci. Technol. 27 (1993) 97.

[7] M.J. Geerdink, Kinetics of microbial degradation of oil-in-soil slurry reactors, Doctoral dissertation, Technical University of the Delft, The Netherlands, 1995, p. 103.

[8] Cassidy, D. P., Efendiev, S., and White, D. M., A comparison of CSTR and SBR bioslurry reactor performance. Water Res., 34 (2000) pp 4333-4342

[9] Cassidy, D. P., Haduk, A. J., Microorganism selection and performance in bioslurry reactors treating $\mathrm{PAH}$ contaminated soil. Environmental Technology, Vol. 23. (2002) pp 1033-1042.

[10] Andrea Giordanoa, Loredana Stantea, Francesco Pirozzib, Raffaele Cesarob, Giuseppe Bortonec, Sequencing batch reactor performance treating PAH contaminated lagoon sediments, Journal of Hazardous Materials B119. (2005) pp 159-166.

[11] S.C. Wilson, K.C. Jones, Bioremediation of soil contaminated with polynuclear aromatic hydrocarbons (PAHs), Environ. Pollut. 81. (1993) pp 229-249

[12] U.S. EPA, Test Methods for Evaluating Solid Waste, Physical/Chemical Methods (EPA, SW-846)

[13] Nelson, D.W., and L.E. Sommers. 1982. Total carbon, organic carbon, and organic matter. pp. 539-579. In A.L. Page, R.H. Miller, and D.R. Keeney (ed.). Methods of soil analysis: Part 2. 2nd. Edition. Book Series No. 9. Amer. Soc. Agron. Madison, WI

[14] ASTM D2487-93 1993, Standard classification of soils for engineering purposes (Unified Soil Classification System). American Society for Testing and Materials.

[15] Cookson J. T. (1995), Bioremediation Engineering. McGraw-Hill, New York.

[16] Eweis, J. B., Ergas, S.J., Change, D. P. Y. and Schroeder, E.D., Bioremediation Principles, McGraw-Hill, New York (1998).

[17] APHA (American Public Health Association). 1992. Standard methods for examination of water and wastewater. Greenberg, A.E., L.S. Clesceri, and A.D. Eaton (Eds.). APHA, AWWA, and WEF, Washington, DC.

[18] Ghiorse WC \& Balkwill DL (1983). Enumeration and morphological characterization of bacteria indigenous to subsurface environments. Develop. Indust. Microbial. 24: 213-224. 